\title{
The Effects of Human Resources Quality, Infrastructure, Leadership, and Communication on E-Government Implementation: A Case of Indonesia Local Government
}

\author{
Yorri Nedy Kumajas \\ Faculty of Economics, Universitas Terbuka, Indonesia \\ yorrikumajas@gmail.com,530022521@ecampus.ut.ac.id
}

\begin{abstract}
This research aimed to examine the effects of human resources quality, infrastructure, leadership, and communication on $e$ government implementation. It used statistical methods and multiple regression analysis to figure out the relationships between variables. Data collection was conducted through observation, questionnaire survey, and literature study or documentation. By applying Slovin's formula to determine the sample size, 245 respondents were obtained from a population of local public officers in the Yapen Islands Regency of Papua. The results show that human resources quality and communication had significant effects on e-government implementation, while infrastructure and leadership did not affect e-government implementation.
\end{abstract}

Keywords

human resources quality, infrastructure; leadership; communication; e-government

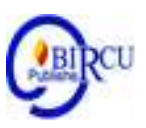

\section{Introduction}

In the 21 st century, or the era widely referred to as the digital era, the most developed information technologies are web- or Internet-based (Sethuraman, 2017). Internet technologies amongst the community can meet the information needs instantly, precisely, and accurately (Setiawan, 2017). This current phenomenon makes information technologies necessary that every individual, group, company, or government institution must fulfill (Cui et al., 2015).

In general, every local government strives to run the government wheel well to realize a good government through better public services (Akib et al., 2016). To this end, both central and local governments have started to implement an electronic government system commonly called e-government (Salsabila \& Purnomo, 2017). To implement this egovernment system, local governments are expected to apply care in seeing and analyzing the factors that can influence its success in a government environment (Stefanovic et al., 2016).

Lee (2009) states that e-government implementation in numerous countries falls short of expectations. Heeks's research (2003) revealed that $35 \%$ of e-government projects in developing countries experienced total failures, $50 \%$ experienced partial failures, and only $15 \%$ were considered successful. Heeks (2003) argued that some factors contributed to e-government implementation failures in developing countries; for example, the public administration system, internal rejection by the government, a lack of plans and strategies, partial, unsystematic e-government introduction, and the insufficient number of human resources. The other factors are an absence of investment plans, the insufficient number of information system and technology vendors, technological immaturity, too much emphasis on technology and technology-based implementation, and hurried implementation without adequate preparation and testing. 
E-government implementation in Indonesia is governed under Presidential Instruction No. 3 of 2003 on National Policies and Strategies, which mandates that ministries or state, provincial, regency, and city institutions across Indonesia must implement e-government in delivering services to the community. Local governments are obliged to provide public services as mandated by Article 22 of Law No. 32 of 2004. There are a total of 15 obligations local governments must exercise, as follows: to protect the public and maintain the national unity, integrity, and harmony, and the Republic of Indonesia; improve the public's quality of life; improve essential educational services; provide health service facilities; provide decent social and public facilities. The above mentioned are part of public services that must be made available by the government, including the government of the Yapen Islands Regency. The government of the Yapen Islands Regency of Papua Province is among the government institutions that have started implementing the e-government system since the launch of the Corruption Eradication Commission action plan of 2017.

The Yapen Islands Regency government has developed information technologies, with the continuous development of various e-government applications in each local government agency (OPD). This process starts with e-planning and e-budgeting implementation, with the support from Regulation of the Minister of Home Affairs No. 90 of 2019 on Classification, Codification, and Nomenclature Regional Planning, Development, and Finance. The local government has also implemented the TPB (supplemental conditional income) application with the backing of Regent Regulation No. 26 of 2019 on Payment of Supplemental Conditional Income to Public Officers in the Yapen Islands Regency Government. This application implementation has generally been in place, but it faces some problems, one of which is the absence of application integration due to unavailable sufficient Internet network.

The other problem was the budget for information infrastructure development in the Yapen Islands Regency, not the priority. It could be seen in the allocated budget for information technology development was relatively small for the last five-years local budget. (APBD - local budget of 2017, 2018, 2019, and 2020). Furthermore, information technology development initiatives are still scattered in each local government agency, leading to the formation of information system cells, lack of complete integration, perceived wasted of the budget that is allocated for information technology devices in a considerable amount in each local government agency, and the generation of outcomes which are not on par with the budget disbursed (Abdiyanto \& Warokka, 2015).

The research by Novita (2014) on the inhibitory factors in e-government development showed that human resources issues inhibit e-government development. Nevertheless, previous research by Dewi and Haryanto (2013) indicated that the education level of the community (human resources) did not significantly influence e-government implementation.

Numerous factors contribute to the problems in e-government implementation in the environment of the Yapen Islands Regency government. Therefore, the researchers conducted a preliminary survey on 40 respondents who came from a couple of local government agencies to determine the factors that influence the success of e-government implementation in the environment of the Yapen Islands Regency government. The survey was conducted via Google Forms, whose link was disseminated to each respondent's WhatsApp contact. This survey involved ten independent variables: organizational culture, organizational structure, policies, human resources, leadership, communication, infrastructure, application, information technology standards, and awareness. Of the ten variables, the researchers extracted the four most voted variables, namely, human resources, infrastructure, leadership, and communication.

Based on the phenomena and research gap described above as well as the observation of some earlier works, coupled with the results of the preliminary survey of the factors that influence e-government implementation in the Yapen Islands Regency, the researchers took an interest in reinvestigating the effects of human resources quality, infrastructure, leadership, and communication on e-government implementation. This research aimed to analyze and describe 
the effects of human resources quality, infrastructure, leadership, and communication on egovernment implementation in the Yapen Islands Regency.

In this study, the researchers set a scope for the variables information and communications infrastructure and leadership to prevent too broad a discussion. The discussion of information and communications infrastructure was restricted only to Internat/Intranet/LAN network, while leadership was restricted to Echelon II.b and Echelon III local government organization leaders.

\section{Review of Literatures}

\subsection{E-Government}

E-government by Khalil et al. (2002) is defined as the use of information technologies, such as a wide area network (WAN), by a government agent. The Internet with mobile computing can transform relationships with the community, businesses, and government institutions. According to Indrajit et al. (2005), e-government is a novel interaction mechanism between the government and the community and other interested parties with information technology (especially the Internet) use for service quality improvement.

\subsection{Human Resources Quality}

As posited by Sedermayanti (2009), quality is a measure that states the extent to which various requirements, specifications, and expectations are fulfilled. Meanwhile, human resources or employees in an organization play an essential role in the organization's success. Human resources quality, according to Matindas (2002), is the willingness of every employee to complete his/her work, develop him-/herself, and encourage his/her colleagues' self-development.

Human resources are one of the factors that affect e-government implementation success (Surdin, 2017). Organizations are in grave need of competent human resources with high knowledge for accurate, practical e-government system use (Choi et al., 2016). Previous research by Ariana et al. (2020), Multama et al. (2018), Probowulan (2016), Novita (2014), and Lee (2009) showed that qualified human resources influence egovernment implementation. Hence, referring to previous empirical findings, the first hypothesis to be proposed is as follows:

H1: Human resources quality affects e-government implementation in the environment of the Yapen Islands Regency government.

\subsection{Infrastructure}

The American Public Works Association in Kodoatie (2005) defines the infrastructure as the physical facilities developed or needed by public agents to serve government functions in the provision of water, electrical power, waste disposal, transportation, and similar services to facilitate social and economic purposes. Meanwhile, Presidential Regulation No. 38 of 2015 defines infrastructure as the technical, physical, and hardware and software facilities needed to provide the community with services and to support structural networks for the community's profitable economic and social growth.

Infrastructure directly influences e-government implementation, and the infrastructure quality determines how successful or failed an e-government program is (Gyamfi et al., 2019; Sami et al., 2011). E-government success needs an appropriate information technology infrastructure to support the systems and applications was developed before the e-government program is implemented (Sirat \& Komputer, 2013). Besides, previous research by Choi et al. (2016), Sorn-In et al. (2015), Novita (2014), AlShlboul et al. (2014), and Sirat (2013) showed that infrastructure influences e-government 
implementation. Hence, referring to previous empirical findings, the second hypothesis to be proposed is as follows:

H2: Infrastructure has an effect on e-government implementation in the environment of the Yapen Islands Regency government.

\subsection{Leadership}

Northouse (2003) says that leadership is an individual's endeavor to control a group for his/her interests. Meanwhile, Dubrin (2015) states that leadership is about instilling belief to win members' support to attain an organization's goals. It also has characteristics of originality, anti-establishment, the acknowledgment that responsibility is in the leader's hands, and commitment to the right things (Rizanuddin, 2020).

Strong leadership is needed to accelerate the e-government implementation process and to deal with the problems that frequently arise due to the involvement of coordination with a variety of sectors (Rante \& Warokka, 2016; CP \& Susanto, 2019). Strong leadership is also vital for ensuring the success of e-government success as an effective leader will influence his organization's employees (Al-Azri et al., 2010). Previous research by CP and Susanto (2019), Al-Shboul (2014), Sirat (2013), Al-Kaabi (2010), and Al-Azri et al. (2010) showed that leadership influences e-government implementation. Thus, referring to previous empirical findings, the third hypothesis proposed is as follows:

H3: Leadership has an effect on e-government implementation in the environment of the Yapen Islands Regency government.

\subsection{Communication}

As stated by Mulyana (2012), communication can be discerned in three manners: communication as one-way action, communication as interaction, and communication as a transaction. Tubbs and Moss, as quoted by Mulyana (2005), further explain that communication is a process of meaning construction between two people or more. Lasswell (2017) defines communication as a one-way message delivery process that may generate an effect.

Communication has a significant effect on the implementation success of a policy because good communication will smoothen the policy implementation according to the goals that have been set when the policy was made (Suriyani, 2018; Hartati, 2020). Ziadi et al. (2016) and Al-Kaabi (2010) showed that communication influences e-government implementation. Thus, referring to previous empirical findings, the fourth hypothesis to be proposed is as follows:

H4: Communication has an effect on e-government implementation in the environment of the Yapen Islands Regency government.

The four hypotheses proposed are then summarized in the following research model (Figure 1).

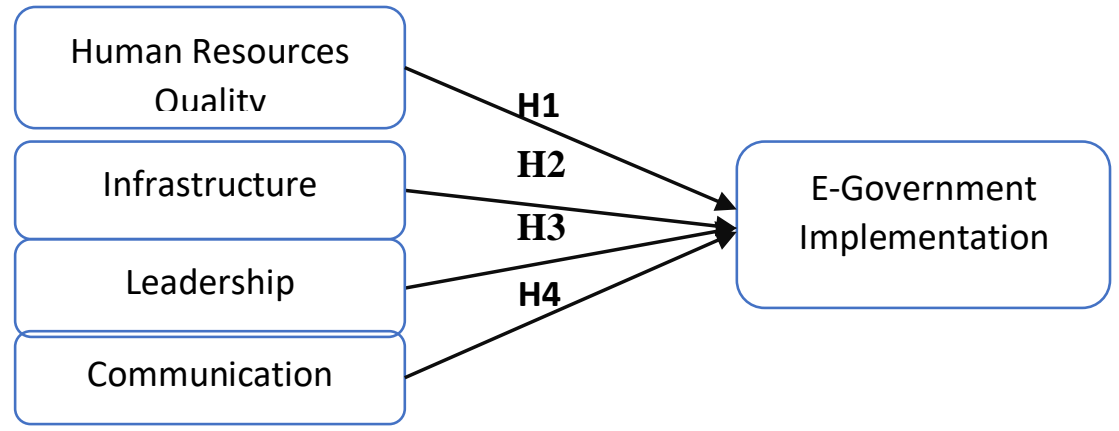

Figure 1. Research Model 


\section{Research Methods}

This research used quantitative methods, which included data collection and analysis with statistical testing methods. The population of this research was 650 state civil officers in several local government agencies in the Yapen Islands Regency in Papua. Slovin's formula was used to determine the sample size. From the returned 246-questionnaires, only 245 questionnaires were used for the next process.

The data analysis methods used in this research consisted of descriptive statistical analysis, research instrument test, classical assumption test, multiple regression analysis, and hypotheses testing. In this research, data were processed with the SPSS version 22. The variables in this research consisted of independent and dependent variables. The independent variables were human resources quality, infrastructure, leadership, and communication, while the dependent variable was e-government implementation.

\section{Results and Discussion}

In this research, the respondents were public officers who worked in the Yapen Islands Regency. Some selected local government agencies served as representatives. These local apparatus organizations were the ones that used e-government the most. The respondents' characteristics were focused on gender, age, latest education level, number of years worked, and position (see Table 1).

Table 1. Respondents' Characteristics Description

\begin{tabular}{|c|c|c|c|}
\hline Categories & Answer Alternatives & $\begin{array}{l}\text { Number of } \\
\text { Respondents }\end{array}$ & $\begin{array}{c}\text { Percentage } \\
(\%)\end{array}$ \\
\hline \multirow[t]{2}{*}{ Gender } & Male & 154 & $62.86 \%$ \\
\hline & Female & 91 & $37.14 \%$ \\
\hline \multirow[t]{3}{*}{ Age } & 20-30 Years & 0 & $0 \%$ \\
\hline & $31-40$ Years & 50 & $20.4 \%$ \\
\hline & $>40$ Years & 195 & $79.6 \%$ \\
\hline \multirow[t]{5}{*}{ Education } & $\begin{array}{c}\text { Senior High } \\
\text { School/equivalent }\end{array}$ & 5 & $2 \%$ \\
\hline & D3 & 18 & $7 \%$ \\
\hline & S1 & 193 & $79 \%$ \\
\hline & S2 & 19 & $12 \%$ \\
\hline & S3 & 0 & 0 \\
\hline \multirow[t]{4}{*}{ Position } & Echelon II & 23 & $15.33 \%$ \\
\hline & Echelon III & 51 & $34.00 \%$ \\
\hline & Echelon IV & 20 & $13.33 \%$ \\
\hline & Staff & 56 & $37.33 \%$ \\
\hline
\end{tabular}

Based on the respondents' characteristics data, the majority of the respondents were male $(62.86 \%)$, aged older than 40 years $(79.6 \%)$, in possession of a Bachelor's degree (79\%), and Echelon III position (34\%).

Descriptive analysis was used to describe the conditions and characteristics of the respondents' answers for each construct/factor or variable studied. The analysis results were used to identify the tendency of the respondents' answers regarding each variable 
studied. The variable human resources quality consisted of eight indicators, infrastructure five indicators, leadership 14 indicators, communication nine indicators, and e-government nine indicators.

The respondents' answers were categorized with an interval calculated by dividing the delta of maximum and minimum scores by five. The calculation yielded an interval of 0.80. According to Sugiyono (2013), with an interval of 0.80 , the categorization system was as follows: 1.00-1.80 (very low); 1.81-2.60 (low); 2.61-3.40 (fair); 3.41-4.20 (high); and 4.21-5.00 (very high).

Table 2. Respondents' Opinions Distribution

\begin{tabular}{|c|c|c|c|c|c|c|c|c|c|}
\hline \multirow{3}{*}{\multicolumn{2}{|c|}{ Items }} & \multicolumn{5}{|c|}{ Opinion Alternatives } & \multirow[t]{3}{*}{ Total } & \multirow[t]{3}{*}{ Means } & \multirow[t]{3}{*}{ Categories } \\
\hline & & SA & A & $\mathrm{N}$ & $\mathrm{D}$ & SD & & & \\
\hline & & 5 & 4 & 3 & 2 & 1 & & & \\
\hline X1.1 & $\begin{array}{l}\text { The staff members } \\
\text { are always healthy }\end{array}$ & 26 & 148 & 59 & 11 & 1 & 245 & 3.76 & High \\
\hline X1.2 & $\begin{array}{l}\text { The staff members } \\
\text { work throughout } \\
\text { the working hours }\end{array}$ & 29 & 155 & 41 & 19 & 1 & 245 & 3.78 & High \\
\hline $\mathrm{X} 1.3$ & $\begin{array}{l}\text { The staff members' } \\
\text { education is equal } \\
\text { to undergraduate } \\
\text { level }\end{array}$ & 18 & 163 & 32 & 26 & 6 & 245 & 3.66 & High \\
\hline X1.4 & $\begin{array}{l}\text { The staff members' } \\
\text { education matches } \\
\text { their main tasks and } \\
\text { functions }\end{array}$ & 7 & 154 & 54 & 25 & 5 & 245 & 3.54 & High \\
\hline $\mathrm{X} 1.5$ & $\begin{array}{l}\text { The staff members } \\
\text { belong to the } \\
\text { information } \\
\text { technology staff }\end{array}$ & 10 & 155 & 44 & 33 & 3 & 245 & 3.56 & High \\
\hline X1.6 & $\begin{array}{l}\text { The staff members' } \\
\text { placement in the } \\
\text { information } \\
\text { technology staff is } \\
\text { appropriate }\end{array}$ & 11 & 120 & 57 & 53 & 4 & 245 & 3.33 & Fair \\
\hline X1.7 & $\begin{array}{l}\text { The staff members } \\
\text { participate in } \\
\text { technical coaching } \\
\text { on information and } \\
\text { communications } \\
\text { technology }\end{array}$ & 21 & 115 & 44 & 60 & 5 & 245 & 3.36 & Fair \\
\hline $\mathbf{X} 1.8$ & $\begin{array}{l}\text { The staff members } \\
\text { are certified } \\
\text { information } \\
\text { technology staffers }\end{array}$ & 16 & 94 & 67 & 59 & 9 & 245 & 3.20 & Fair \\
\hline Mean & & & & & & & & 3.52 & High \\
\hline X2.1 & $\begin{array}{l}\text { A working space is } \\
\text { provided }\end{array}$ & 36 & 173 & 30 & 6 & - & 245 & 3.97 & High \\
\hline $\mathrm{X} 2.2$ & $\begin{array}{l}\text { A desk and a chair } \\
\text { are provided }\end{array}$ & 38 & 178 & 24 & 5 & - & 245 & 4.01 & High \\
\hline $\mathrm{X} 2.3$ & $\begin{array}{l}\text { A computer is } \\
\text { provided }\end{array}$ & 11 & 161 & 42 & 30 & 1 & 245 & 3.61 & High \\
\hline
\end{tabular}




\begin{tabular}{|c|c|c|c|c|c|c|c|c|c|}
\hline $\mathrm{X} 2.4$ & $\begin{array}{l}\text { Connection to LAN } \\
\& \text { the Internet is } \\
\text { available }\end{array}$ & 8 & 136 & 56 & 43 & 2 & 245 & 3.42 & High \\
\hline $\mathrm{X} 2.5$ & $\begin{array}{l}\text { A server room is } \\
\text { available }\end{array}$ & 14 & 164 & 52 & 15 & - & 245 & 3.72 & High \\
\hline Mean & & & & & & & & 3.75 & High \\
\hline X3.1 & $\begin{array}{l}\text { A strong } \\
\text { relationship is built } \\
\text { with staff members }\end{array}$ & 47 & 191 & 7 & - & - & 245 & 4.16 & High \\
\hline X3.2 & $\begin{array}{l}\text { The leader always } \\
\text { motivates the staff } \\
\text { members }\end{array}$ & 66 & 172 & 5 & 2 & - & 245 & 4.23 & Very High \\
\hline X3.3 & $\begin{array}{l}\text { The leader is able } \\
\text { to work extra time }\end{array}$ & 49 & 158 & 19 & 15 & 4 & 245 & 3.95 & High \\
\hline X3.4 & $\begin{array}{l}\text { The leader requests } \\
\text { subordinates to } \\
\text { complete the work } \\
\text { on time }\end{array}$ & 40 & 188 & 12 & 5 & - & 245 & 4.07 & High \\
\hline X3.5 & $\begin{array}{l}\text { The leader is } \\
\text { present on time }\end{array}$ & 38 & 177 & 22 & 8 & - & 245 & 4.00 & High \\
\hline X3.6 & $\begin{array}{l}\text { The leader makes } \\
\text { decision through } \\
\text { deliberations }\end{array}$ & 37 & 181 & 25 & 2 & - & 245 & 4.03 & High \\
\hline X3.7 & $\begin{array}{l}\text { The leader solves } \\
\text { problems } \\
\text { accurately }\end{array}$ & 28 & 193 & 24 & - & - & 245 & 4.02 & High \\
\hline X3.8 & $\begin{array}{l}\text { The leader is able } \\
\text { to examine } \\
\text { problems }\end{array}$ & 22 & 186 & 32 & 5 & - & 245 & 3.92 & High \\
\hline X3.9 & $\begin{array}{l}\text { The leader supports } \\
\text { information } \\
\text { technology } \\
\text { developers }\end{array}$ & 43 & 174 & 26 & 2 & - & 245 & 4.05 & High \\
\hline X3.11 & $\begin{array}{l}\text { The leader is } \\
\text { directly involved in } \\
\text { e-government } \\
\text { implementation }\end{array}$ & 35 & 171 & 37 & 2 & - & 245 & 3.97 & High \\
\hline X3.11 & $\begin{array}{l}\text { The leader always } \\
\text { inspects the } \\
\text { information and } \\
\text { communications } \\
\text { technologies' } \\
\text { conditions }\end{array}$ & 36 & 149 & 35 & 21 & 4 & 245 & 3.78 & High \\
\hline X3.12 & $\begin{array}{l}\text { The leader involves } \\
\text { subordinates in } \\
\text { technical coaching } \\
\text { on information and } \\
\text { communications } \\
\text { technologies }\end{array}$ & 44 & 175 & 21 & 5 & - & 245 & 4.05 & High \\
\hline X3.1? & $\begin{array}{l}\text { The leader puts } \\
\text { broader interests } \\
\text { first }\end{array}$ & 22 & 136 & 30 & 40 & 17 & 245 & 3.43 & High \\
\hline
\end{tabular}




\begin{tabular}{|c|c|c|c|c|c|c|c|c|c|}
\hline X3.14 & $\begin{array}{l}\text { The leader is able } \\
\text { to complete tasks } \\
\text { both individually } \\
\text { and in groups }\end{array}$ & 17 & 182 & 12 & 25 & 9 & 245 & 3.71 & High \\
\hline Mean & & & & & & & & 3.95 & High \\
\hline X4.1 & $\begin{array}{l}\text { The organization's } \\
\text { vision and missions }\end{array}$ & 36 & 194 & 14 & 1 & - & 245 & 4.08 & High \\
\hline X4.2 & $\begin{array}{l}\text { SOP on main tasks } \\
\text { and functions is in } \\
\text { place }\end{array}$ & 33 & 203 & 9 & - & - & 245 & 4.10 & High \\
\hline $\mathrm{X} 4.3$ & $\begin{array}{l}\text { Clear instructions } \\
\text { are in place }\end{array}$ & 27 & 212 & 5 & 1 & - & 245 & 4.08 & High \\
\hline X4.4 & $\begin{array}{l}\text { Information } \\
\text { regarding policies } \\
\text { and rules is } \\
\text { available }\end{array}$ & 45 & 187 & 13 & - & - & 245 & 4.13 & High \\
\hline $\mathrm{X} 4.5$ & $\begin{array}{l}\text { Reports on work } \\
\text { outcomes are } \\
\text { available }\end{array}$ & 36 & 198 & 10 & 1 & - & 245 & 4.10 & High \\
\hline X4.6 & $\begin{array}{l}\text { Support } \\
\text { information } \\
\text { openness }\end{array}$ & 39 & 185 & 18 & 3 & - & 245 & 4.06 & High \\
\hline X4.7 & $\begin{array}{l}\text { Communication } \\
\text { between units runs } \\
\text { effectively }\end{array}$ & 31 & 194 & 19 & 1 & - & 245 & 4.04 & High \\
\hline $\mathrm{X} 4.8$ & $\begin{array}{l}\text { There are } \\
\text { coordination and } \\
\text { collaborations } \\
\text { between work units }\end{array}$ & 40 & 186 & 19 & - & - & 245 & 4.08 & High \\
\hline $\mathrm{X} 4.9$ & $\begin{array}{l}\text { There are } \\
\text { exchanges of } \\
\text { information } \\
\text { between local } \\
\text { government } \\
\text { agencies }\end{array}$ & 52 & 170 & 20 & 3 & - & 245 & 4.10 & High \\
\hline Means & & & & & & & & 4.08 & High \\
\hline Y.1 & $\begin{array}{l}\text { Regional regulation } \\
\text { on e-government is } \\
\text { in place }\end{array}$ & 3 & 30 & 97 & 72 & 43 & 245 & 2.50 & Low \\
\hline Y.2 & $\begin{array}{l}\text { There is } \\
\text { coordination } \\
\text { between local } \\
\text { government } \\
\text { agencies regarding } \\
\text { e-government } \\
\text { implementation }\end{array}$ & 9 & 182 & 39 & 14 & 1 & 245 & 3.75 & High \\
\hline Y.3 & $\begin{array}{l}\text { Local apparatus } \\
\text { organizations } \\
\text { support e- } \\
\text { government } \\
\text { implementation }\end{array}$ & 19 & 192 & 26 & 8 & - & 245 & 3.74 & High \\
\hline
\end{tabular}




\begin{tabular}{|c|c|c|c|c|c|c|c|c|c|}
\hline Y.4 & $\begin{array}{l}\text { Support the satu } \\
\text { data program }\end{array}$ & 26 & 186 & 29 & 4 & - & 245 & 3.95 & High \\
\hline Y.5 & $\begin{array}{l}\text { Local government } \\
\text { agencies can access } \\
\text { regional } \\
\text { government data }\end{array}$ & 25 & 184 & 31 & 5 & - & 245 & 3.93 & High \\
\hline Y.6 & $\begin{array}{l}\text { Local government } \\
\text { agencies have an e- } \\
\text { government } \\
\text { application related } \\
\text { to main tasks and } \\
\text { functions }\end{array}$ & 14 & 115 & 68 & 39 & 9 & 245 & 3.31 & Fair \\
\hline Y.7 & $\begin{array}{l}\text { Local government } \\
\text { agencies } \\
\text { understand and } \\
\text { keep an update on } \\
\text { information } \\
\text { technology } \\
\text { development }\end{array}$ & 16 & 174 & 34 & 16 & 5 & 245 & 3.73 & High \\
\hline Y.8 & $\begin{array}{l}\text { Local government } \\
\text { agencies have } \\
\text { reliable } \\
\text { admins/operators in } \\
\text { running e- } \\
\text { government } \\
\text { application }\end{array}$ & 13 & 159 & 49 & 21 & 3 & 245 & 3.64 & High \\
\hline & & & Mean & & & & & 3.56 & High \\
\hline
\end{tabular}

Note: $\mathrm{SD}=$ Strongly Disagree; $\mathrm{D}=$ Disagree; $\mathrm{N}=$ Neutral; $\mathrm{A}=$ Agree; $\mathrm{SA}=$ Strongly Agree; X1 = Human Resources Quality; X2 = Infrastructure; X3 = Leadership; $\mathrm{X} 4$ = Communication; $\mathrm{Y}=\mathrm{E}-$ Government .

Based on the respondents' opinions distribution presented in Table 2, the respondents had an overall judgment that human resources quality, infrastructure, leadership, and communication had strong effects on e-government implementation. This finding is seen in the mean scores generated-3.52, 3.75, 3.95, 4.08, and 3.56, respectively which belonged to the high category (within the range $3.41-4.20$ ).

Table 3. Results of Validity and Reliability Tests

\begin{tabular}{lcc}
\hline Items & R Count & Cronbach's Alpha \\
\hline X1.1 & 0.298 & \\
X1.2 & 0.501 & \\
X1.3 & 0.482 & \\
X1.4 & 0.470 & \\
X1.5 & 0.618 & \\
X1.6 & 0.766 & \\
X1.7 & 0.711 & \\
X1.8 & 0.797 & \\
X2.1 & 0.722 & \\
X2.2 & 0.748 & \\
X2.3 & 0.780 &
\end{tabular}




\begin{tabular}{|c|c|c|}
\hline & & \\
\hline X2.4 & 0.686 & \\
\hline $\mathrm{X} 2.5$ & 0.525 & \\
\hline X3.1 & 0.585 & \\
\hline X3.2 & 0.527 & \\
\hline X3.3 & 0.444 & \\
\hline X3.4 & 0.565 & \\
\hline X3.5 & 0.409 & \\
\hline X3.6 & 0.433 & \\
\hline X3.7 & 0.524 & \\
\hline X3.8 & 0.739 & 0.857 \\
\hline X3.9 & 0.735 & \\
\hline X3.10 & 0.701 & \\
\hline X3.11 & 0.728 & \\
\hline X3.12 & 0.720 & \\
\hline X3.13 & 0.690 & \\
\hline X3.14 & 0.684 & \\
\hline X4.1 & 0.689 & \\
\hline X4.2 & 0.570 & \\
\hline X4.3 & 0.628 & \\
\hline X4.4 & 0.651 & \\
\hline X4.5 & 0.670 & 0.849 \\
\hline X4.6 & 0.726 & \\
\hline X4.7 & 0.702 & \\
\hline X4.8 & 0.731 & \\
\hline X4.9 & 0.698 & \\
\hline Y.1 & 0.432 & \\
\hline Y.2 & 0.455 & \\
\hline Y.3 & 0.576 & \\
\hline Y.4 & 0.534 & 0623 \\
\hline Y.5 & 0.441 & 0.633 \\
\hline Y.6 & 0.752 & \\
\hline Y.7 & 0.576 & \\
\hline Y.8 & 0.517 & \\
\hline
\end{tabular}

A validity test is aimed to indicate the level of validity of an instrument (Ridwan \& Sunarto, 2013). Validity testing was conducted with the Pearson Product Moment test. The result shows that all the statements had $r$-statistic values more significant than the table of 0.125 , meaning that all the statements were valid. Other than the validity test, a reliability test was also conducted to examine whether the instrument had a high-reliability level. The result shows that all the variables had Cronbach's alpha values greater than 0.6 , meaning that all the variables were reliable. 
Table 4. Results of Classical Assumption Test

\begin{tabular}{ccccccc}
\hline \multicolumn{2}{c}{ Normality Test } & \multicolumn{3}{c}{ Multicollinearity Test } & \multicolumn{2}{c}{$\begin{array}{c}\text { Heteroscedasticity } \\
\text { Test }\end{array}$} \\
\hline $\begin{array}{c}\text { Kolmogorov } \\
\text { Smirnov }\end{array}$ & $\begin{array}{c}\text { Asymp. } \\
\text { Sig }\end{array}$ & Variables & Tolerance & VIF & Sig. Value & $\begin{array}{c}\text { Sig. } \\
\text { Limit }\end{array}$ \\
\hline \multirow{2}{*}{$\mathbf{0 . 9 0 5}$} & & $\mathrm{X} 1$ & 0.690 & 1.449 & 0.110 & 0.05 \\
\cline { 3 - 7 } & \multirow{2}{*}{0.386} & $\mathrm{X} 2$ & 0.765 & 1.307 & 0.938 & 0.05 \\
\cline { 3 - 7 } & & $\mathrm{X} 3$ & 0.442 & 2.263 & 0.993 & 0.05 \\
\cline { 3 - 7 } & & $\mathrm{X} 4$ & 0.469 & 2.134 & 0.523 & 0.05 \\
\hline
\end{tabular}

The classical assumption test is one of the requirements that must be fulfilled before conducting multiple regression analysis. This test consists of the normality test, multicollinearity test, and heteroscedasticity test. A normality test was conducted to examine whether the variables in the regression model had normally-distributed data or not. The result shows that Asymp. Sig obtained was 0.386, which was greater than 0.05. Thus, it can be said that the data were normally distributed.

A multicollinearity test was conducted to figure out whether in the regression model a correlation between independent variables was present. The result shows that all the independent variables had tolerance values $>0.10$. This finding means that no problem was found in the multicollinearity test. Besides, from the VIF calculation, all the independent variables had VIF values < 10. It can be concluded that no multicollinearity was present between the independent variables in the regression model. Then, a heteroscedasticity test was conducted to figure out whether there was a similarity in the variability of residuals across different observations. A regression model meets the requirement if it has the same variability of residuals from one observation to another.

Table 5. Results of Multiple Regression Analysis and Hypotheses Testing

\begin{tabular}{|c|c|c|c|c|c|}
\hline \multirow[b]{2}{*}{ Model } & \multicolumn{2}{|c|}{$\begin{array}{l}\text { Unstandardized } \\
\text { Coefficients }\end{array}$} & \multirow{2}{*}{$\begin{array}{c}\text { Standardized } \\
\text { Coefficients } \\
\text { Beta } \\
\end{array}$} & \multirow[b]{2}{*}{$\mathrm{t}$} & \multirow[b]{2}{*}{ Sig. } \\
\hline & $\mathrm{B}$ & Std. Error & & & \\
\hline $\begin{array}{ll}1 \text { (Constant }) \\
\end{array}$ & 2.944 & 1.976 & & 1.490 & .137 \\
\hline Human resources quality & .306 & .042 & .406 & 7.207 & .000 \\
\hline Infrastructure & .102 & .069 & .079 & 1.477 & .141 \\
\hline Leadership & .020 & .039 & .037 & .520 & .603 \\
\hline Communication & .385 & .074 & .356 & 5.201 & .000 \\
\hline Adjusted R Square & 0.466 & & & & \\
\hline
\end{tabular}

Dependent Variable: E-Government Implementation

Based on the heteroscedasticity testing with the Glejser test, the result of which is presented in Table 4, it can be concluded that each independent variable had a sig.-value greater than 0.05. In other words, no heteroscedasticity was present.

Based on the result of the SPSS- (Statistical Product and Service Solutions) aided multiple regression analysis as shown in Table 4.5, the following regression equation was obtained:

$\mathrm{Y}=2.944+0.306 \mathrm{X}_{1}+0.102 \mathrm{X}_{2}+0.020 \mathrm{X}_{3}+0.385 \mathrm{X}_{4}$ 
Based on the regression equation calculated above, the effects of human resource quality (X1), infrastructure (X2), leadership (X3), and communication (X4) on egovernment $(\mathrm{Y})$ can be explained as follows:

1. The constant $=2.944$ denotes that if human resources quality (X1), infrastructure (X2), leadership (X3), and communication (X4) were held constant, e-government (Y) would have a value of 2.944 .

2. The coefficient of the variable human resources quality was 0.306 . The positive mark of the coefficient would mean that for every increase of the quality of a human resource (X1) unit, e-government (Y) would increase by 0.306, with the assumption that the variables infrastructure (X2), leadership (X3), and communication (X4) had constant values.

3. The coefficient of the variable infrastructure was 0.102 . The positive mark of the coefficient would mean that for every increase of an infrastructure (X2) unit, egovernment $(\mathrm{Y})$ would increase by 0.102 , with the assumption that the variables human resources quality (X1), leadership (X3), and communication (X4) had constant values.

4. The coefficient of the variable leadership was 0.020. The positive mark of the coefficient would mean that for every increase of a leadership (X3) unit, e-government (Y) would increase by 0.020 , with the assumption that the variables human resources quality (X1), infrastructure (X2), and communication (X4) had constant values.

5. The coefficient of the variable communication was 0.385 . The positive mark of the coefficient would mean that for every increase of a leadership (X3) unit, e-government (Y) would increase by 0.385 , with the assumption that the variables human resources quality (X1), infrastructure (X2), and leadership (X3) had constant values.

To examine the effects of independent variables on the dependent variable, a t-test was conducted. The t-statistics of the variable human resources quality was 7.207 , which was greater than the t table 1.651, and the sig.-level was 0.000 . It could be concluded that human resources quality (X1) significantly affected e-government implementation in the Yapen Islands Regency. Thus, the first hypothesis saying that human resources quality affects e-government implementation in the Yapen Islands Regency, was accepted.

This result is in line with the research by Ariana et al. (2020), Multama et al. (2018), Probowulan (2016), Novita (2014), and Lee (2009), which stated that human resource quality affects e-government implementation. This finding means that when human resources quality is improved, e-government implementation will become easier. In the context of the quality of the human resources of public officers (ASN) in the Yapen Islands Regency government, the role of human resources was central in the effort to achieve the regency's vision and missions. Human resources quality was highly influential to egovernment implementation. With human resources of quality, the existing e-government applications in local government organizations will be operable.

The variable infrastructure had t-statistics of 1.477, which was smaller than the ttable of 1.651, and the sig.-level was 0.141 . It could be concluded that infrastructure (X2) had no effect on e-government implementation in the Yapen Islands Regency government. Thus, the second hypothesis saying that infrastructure affects e-government implementation in the environment of the Yapen Islands Regency, was rejected.

This result is not in line with the research by Choi et al. (2016), Sorn-In et al. (2015), Novita (2014), Al-Shlboul et al. (2014), and Sirat (2013), but it agrees with that by Riyadh et al. (2019). Infrastructure had no significant effect on e-government implementation because of the challenges the government was facing in information technology infrastructure development (Riyadh et al., 2019). 
Referring to the descriptive analysis results, the statement "Connection to LAN \& the Internet is available" had a mean value of 3.42. The statement in the indicator X2.4 was perceived as the lowest among the five statements (indicators). This low score came from the fact that only a few local government organizations were connected to LAN and Internet networks. Based on the fact in the field, the e-government of the Yapen Islands Regency had featured the Corruption Eradication Commission program through the Corruption Eradication Commission Action Plan of 2017. However, to date, information and communications technology infrastructure have yet to become a priority in the development program of the Yapen Islands Regency. The local government was still dependent on central government aids, which were only aimed to stimulate local governments. This fact is as evident in the smaller amount of budget allocated for information and communications technologies than to other sectors. The 2020 activity programs in the Local Information and Communications Office, which was assigned with main tasks in information and communications technology infrastructure development, were allocated with an infrastructure fund of no more than Rp1.5 billion, equal to USD 100,000 (DPA Dinas Kominfo 2020).

The t-statistics of the next variable, leadership, was 0.520 , which was smaller than the t table of 1.651, and the sig.-value was 0.603 . It could be concluded that leadership (X3) had no partial effect on e-government implementation in the Yapen Islands Regency. Thus, the third hypothesis saying that leadership affects e-government implementation in the Yapen Islands Regency was rejected.

This result is not in line with the research by CP and Susanto (2019), Al-Shboul (2014), Sirat (2013), Al-Kaabi (2010), and Al-Azri et al. (2010), but it agrees with the research by Husain and Fauziati (2018) and Wicaksono (2013). Based on the respondents' opinions distribution, the statement "The leaders put broader interests first" had a mean value of 3.43. In other words, the statement in the indicator X3.13 was perceived as the lowest among the 14 statements (indicators), with a mean value (3.43) belonging to the neutral category. This finding is attributed to the leaders' differing leadership styles, in which case there were some who were focused more on broader interests and there were some who focused more on the internal interests of their respective local government agency or on doing something according to their main tasks and functions.

The $t$ count of the variable communication was 5.201, which was greater than the $t$ table of 1.651, and the sig.-level was 0.000 . It could be concluded that communication (X4) had a significant effect on e-government implementation. Thus, the fourth hypothesis saying that communication affects e-government implementation in the Yapen Islands Regency, was accepted.

This result is in line with the research by Ziadi et al. (2016) and Al-Kaabi (2010), which stated that communication affects e-government implementation. The fact in the field indicates that communication in the environment of the Yapen Islands Regency government had a central role, especially in the satu (one) data program or the data center of the regency. Communication is critical for improving coordination between local apparatus organizations, particularly in data exchange or processing. For instance, the Regional Development Planning Agency (Bappeda) of the Yapen Islands Regency established good communication for smooth collection of local government agency's work planning data to draft the regional planning documents (RKPD) available in the E-Planning application. The implementation of e-government should be supported by good communication between local apparatus organizations. In other words, the better the communication established, the better the e-government implementation. Thus, it can be 
said that communication significantly influenced e-government implementation in the Yapen Islands Regency.

Lastly, the $\mathrm{R}^{\text {-squared }}$ (coefficient of determination) test was conducted to measure the ability of the variables human resources quality (X1), infrastructure (X2), leadership (X3), and communication (X4) to explain the variation in the variable e-government implementation (Y). The adjusted R-squared value obtained from the test was 0.466 . The interpretation for this value is that $46.6 \%$ of the dependent variable e-government implementation was influenced by the independent variables human resources quality, infrastructure, leadership, and communication. The remaining $53.34 \%$ was influenced by other variables unexplored in this research.

\section{Conclusion}

This research examined the effects of human resources quality, infrastructure, leadership, and communication on e-government implementation in the Yapen Islands Regency. Based on the results of the tests conducted, the following conclusions were drawn. First, human resources quality affected e-government implementation. This finding means that if the human resources' quality is improved, e-government implementation in the Yapen Islands Regency will become easier. Second, infrastructure and leadership did not influence the success of e-government implementation in the Yapen Islands Regency. Finally, communication had an effect on e-government implementation in the Yapen Islands Regency. The better the communication, the better the e-government implementation.

The results of this research have several critical implications. First, the local government agencies in the Yapen Islands Regency should continuously improve the quality of their public officers through both improved education and training to enhance their ability to run e-government successfully. Then, better and improved-communication networks and platforms should be established among local government agencies in the Yapen Islands Regency to ensure a better and coordinated e-government implementation.

It is also expected that leaders of local government agencies play a greater role in egovernment implementation, giving a more significant force to their leadership role in influencing e-government implementation. Concerning infrastructure, the Yapen Islands Regency, through local government agencies' main tasks and functions, are expected to continuously improve and give priority to network infrastructure development for the egovernment implementation to operate as designed.

\section{References}

Abdiyanto \& Warokka, A. (2015). Priority-Driven Budgeting Policy and Regional Inequality: Does Economic Structure Transformation Really Perform as Intervening Variable? Journal of Economics Studies and Research, 5(2), 1-18.

Afriani, K., \& Wahid, F. (2009). Dampak e-government pada good governance: Temuan empiris dari kota jambi. Seminar Nasional Aplikasi Teknologi Informasi (SNATI).

Akib, M., Habbe, A. H., Rura, Y., \& Hakim, A. (2016). Relationship Good Governance with Welfare Society Mediated by Local Government Financial Disclosure and Audit Report Opinion (Study on Local Government South Southeast Sulawesi). International Journal of Science and Research (IJSR), 5(2), 789-800. https://doi.org/10.21275/v5i2.nov161150

Al-Azri, A., Al-Salti, Z., \& Al-Karaghouli, W. (2010). The successful implementation of e-government transformation: A case study in Oman. 
Al-Kaabi, R. (2010). Secure and failure factors of e-government projects implementation in developing country: A study on the implementation of Kingdom of Bahrain. International Journal of Information and Communication Engineering, 4(6), 659-662.

Al-Shboul, M., Rababah, O., Ghnemat, R., \& Al-Saqqa, S. (2014). Challenges and factors affecting the implementation of e-government in Jordan. Journal of Software Engineering and Applications, 7(13), 1111.

Ariana, S., Azim, C., \& Antoni, D. (2020). Clustering of ICT human resources capacity in the implementation of E-government in expansion area: a case study from pali regency. Cogent Business \& Management, 7(1), 1754103.

Choi, H., Park, M. J., Rho, J. J., \& Zo, H. (2016). Rethinking the assessment of egovernment implementation in developing countries from the perspective of the design-reality gap: Applications in the Indonesian e-procurement system. Telecommunications Policy, 40(7), 644-660.

CP, Y. H., \& Susanto, T. D. (2019). E-Leadership: The Effect of E-Government Success in Indonesia. Journal of Physics: Conference Series, 1201(1), 12025.

Cui, T., Ye, H. J., Teo, H. H., \& Li, J. (2015). Information technology and open innovation: A strategic alignment perspective. Information \& Management, 52(3), 348-358.

Dewi, A. S., \& Haryanto, H. (2013). Faktor-faktor Yang Mempengaruhi Implementasi Egovernment (Studi Pada Pemerintah Daerah Tingkat Provinsi Di Indonesia). Fakultas Ekonomika dan Bisnis.

DuBrin, A. J. (2015). Leadership: Research findings, practice, and skills. Nelson Education.

Gyamfi, G. D., Gyan, G., Ayebea, M., Nortey, F. N. N., \& Baidoo, P. Y. (2019). Assessing the Factors Affecting the Implementation of E-Government and Effect on Performance of DVLA. International Journal of Electronic Government Research (IJEGR), 15(1), 47-61.

Hartati, T. (2020). The Role of Human Relations in Increasing Employee Performance. Budapest International Research and Critics Institute-Journal (BIRCI-Journal), 3(1), 127-133.

Heeks, R. (2003). Most eGovernment-for-development projects fail: how can risks be reduced?

Husain, S. M., \& Fauziati, P. (2018). Faktor-Faktor yang Mempengaruhi Implementasi EGovernment (Studi Empiris Pada Organisasi Perangkat Daerah di Kota Padang). Jurnal Fakultas Ekonomi, 13(1).

Indrajit, R. E., Zainudin, A., \& Rudianto, D. (2005). Electronic government in action. Yogyakarta: Andi Yogyakarta.

Khalil, M. A., Lanvin, B. D., \& Chaudhry, V. (2002). The e-government handbook for developing countries. World Bank/Centre for Democracy Technology, 1-41.

Kodoatie, R. J. (2005). Pengantar manajemen infrastruktur. Yogyakarta: Pustaka Pelajar.

Lasswell, H. D. (2017). The Signature of Power: Buildings, Communications, and Policy. Routledge.

Lee, N. G. (2009). Penerapan e-Government, Seri Modul 3, Asian and Pacific Training Centre For Information And Communication Technology For Development.

Multama, I., Asniati, A., \& Rahman, A. (2018). Analysis of the Effect of E-Government Implementation on Quality of Information Towards Government to Government. International Conference on Business, Economic, Social Science and Humanities

Mulyana, D. (2005). Human communication: Prinsip-prinsip dasar. Bandung: PT. Remaja Rosdakarya.

Novita, D. (2014). Faktor-Faktor Penghambat Pengembangan E-Government: Studi Kasus Pemerintah Kota Palembang, Sumatera Selatan. Jurnal Eksplora Informatika, 4(1), 43-52. 
Probowulan, D. (2016). Dampak Teknologi Informasi dan Sumber Daya Manusia terhadap Penerapan E-Government Sebagai Bentuk Pelayanan Publik. BALANCE: Economic, Business, Management and Accounting Journal, 13(01).

Rante, A.,\& Warokka, A. (2016). Leadership style, decentralisation and managerial performance: Does the management accounting system mediate the relationship? Journal for Global Business Advancement, 9 (1), 79-89.

Republik Indonesia. Instruksi Presiden Republik Indonesia Nomor 3 Tahun 2003 tentang Kebijakan dan Strategi Nasional Pengembangan e-government.

Republik Indonesia. Undang-Undang Nomor 32 Tahun 2004 tentang Pemerintahan Daerah.

Ridwan, \& Sunarto. (2013). Pengantar Statistika: Untuk Penelitian Pendidikan, Sosial, Ekonomi, Komunikasi, dan Bisnis. Alfabeta.

Rizanuddin, H. (2020). Influences of Career Planning, Leadership and Organizational Culture towards Employee Work Effectiveness. Budapest International Research and Critics Institute-Journal (BIRCI-Journal), 3(3), 1791-1799.

Salsabila, L., \& Purnomo, E. P. (2017). Establishing and Implementing Good Practices EGovernment (A Case Study: e-Government Implementation between Korea and Indonesia). ASEAN/Asian Academic Society International Conference Proceeding Series.

Sami, M., Abdullah, H.H., Othman, M.Z., Warokka, A. (2011). Quality of Information as Strategic Factor in Accounting Information System (AIS) towards Better Organizational Performance. JRMSI-Jurnal Riset Manajemen Sains Indonesia, 2(2), 1-17.

Sethuraman, K. R. (2017). The Roles for Information Communication Technology, Web2.0 and Internet of Things in Curricular Delivery and Assessment in 21st Century. SBV Journal of Basic, Clinical and Applied Health Science, 1(A1), 42-44. https://doi.org/10.5005/jp-journals-10082-01107

Setiawan, W. (2017). Era digital dan tantangannya.

Sorn-In, K., Tuamsuk, K., \& Chaopanon, W. (2015). Factors affecting the development of e-government using a citizen-centric approach. Journal of Science \& Technology Policy Management.

Stefanovic, D., Marjanovic, U., Delić, M., Culibrk, D., \& Lalic, B. (2016). Assessing the success of e-government systems: An employee perspective. Information \& Management, 53(6), 717-726.

Sugiyono. (2013). Metode Penelitian Kuantitatif, Kualitatif dan R\&D. Alfabeta.CV.

Surdin, J. (2017). Analisis kelayakan implementasi e-government dalam pelayanan publik di bidang keagrariaan di kabupaten pinrang. KAREBA: Jurnal Ilmu Komunikasi, $5(1), 178-191$.

Suriyani, E. (2018). Implementasi Penyelenggaraan E-Government (Studi Kasus Peraturan Bupati Tabalong Nomor 09 Tahun 2017). Jurnal PubBis, 2(2), 161-181.

Ziadi, A. R., Yossomsakdi, S., \& Wijaya, A. F. (2016). The Implementation of EGovernment (Smart City Program) to Achieve an Effective Public Service (Case Studies on Qlue and CROP in Management Unit of Jakarta Smart City). International Conference on Ethics of Business, Economics, and Social Science, 434-440. 